\title{
Pengaruh Konsumsi Buah Pepaya California dan Pepaya Hawai terhadap Penurunan Indeks Debris Anak
}

\author{
Swisela O. Tumembow \\ Vonny N. S. Wowor \\ Elita Tambunan \\ Program Studi Pendidikan Dokter Gigi Fakultas Kedokteran \\ Universitas Sam Ratulangi Manado \\ Email: stumembow@gmail.com
}

\begin{abstract}
Poor oral hygiene as well as bad diet may affect teeth and oral health, resulting in tooth disordes such as caries. Consumption of fruits rich of fibers and water can accelerate tooth cleansing, therefore, debris can be reduced and tooth caries can be avoided. Papaya (Carica papaya) contains vitamins, minerals, and enzymes for digestion as well as fibers and water. This study was aimed to determine the effect of Californian and Hawaiian papaya consumption on reduction of debris index among children. This was an experimental study with a one-shot case study pre-experimental design and a pretest-postest approach. In this study, there were 32 respondents of third grade students of Sekolah Dasar Inpres Kaiwatu Manado (elementary school) with an age range of 8-10 years obtained by using total sampling technique. The results of t-tests in debris index before and after Hawaiian and Californian papaya consumption showed significant $P$-values $(P<0.0001)$. The average reduction of debris index after Californian papaya consumption was 1.31 and after Hawaiian papaya consumption was 1.71. The independent T-test showed a $P$ value of $0.010(P<0.05)$. Conclusion: Consumption of Hawaiian and Californian papayas could reduce debris index among children. Moreover, consumption of Hawaiian papaya was more effective in reducing debris index compared to Califonian papaya.
\end{abstract}

Keywords: Californian papaya, Hawaiian papaya, debris index

\begin{abstract}
Abstrak: Kebersihan gigi dan mulut serta pola konsumsi makanan yang kurang baik dapat memengaruhi kesehatan gigi dan mulut, salah satunya yaitu kerusakan pada gigi seperti karies gigi. Konsumsi buah yang banyak mengandung serat dan air dapat melancarkan pembersihan pada gigi, sehingga luas permukaan debris dapat dikurangi dan karies gigi dapat dicegah. Pepaya (Carica papaya) mengandung vitamin, mineral, dan enzim yang berguna untuk pencernaan, serta serat dan air. Penelitian ini bertujuan untuk mengetahui pengaruh konsumsi buah pepaya California dan pepaya Hawai terhadap penurunan indeks debris pada anak. Jenis penelitian ialah eksperimental dengan rancangan pra-eksperimental one-shot case study pendekatan pretest-posttest. Responden penelitian yaitu 32 siswa kelas 3 SD Inpres Kaiwatu Manado berusia 8-10 tahun, diperoleh berdasarkan total sampling. Hasil penelitian indeks debris sebelum dan sesudah mengonsumsi pepaya California dan pepaya Hawai mendapatkan nilai signifikansi hasil uji-t berpasangan keduanya masing-masing dengan $P<0,0001$. Rerata penurunan indeks debris setelah mengonsumsi pepaya California 1,31 dan setelah mengonsumsi pepaya Hawai 1,71. Hasil uji-t tidak berpasangan mendapatkan nilai $P=0,010(<0,05)$. Simpulan: Konsumsi pepaya California dan pepaya Hawai dapat menurunkan indeks karies secara bermakna pada anak. Selain itu, konsumsi pepaya Hawai lebih berpengaruh terhadap penurunan indeks karies dibandingkan konsumsi pepaya California.
\end{abstract}

Kata kunci: pepaya California, pepaya Hawai, indeks debris 
Kesehatan gigi dan mulut merupakan bagian dari kesehatan tubuh secara keseluruhan yang tak kalah penting untuk diperhatikan oleh masyarakat. Gigi dan mulut merupakan pintu masuk bagi berbagai kuman yang dapat menimbulkan penyakit pada tubuh. Oleh karena itu kesehatan gigi dan mulut pun perlu mendapat perhatian. Masalah kesehatan gigi dan mulut yang sering terjadi yaitu karies.

Karies merupakan suatu penyakit pada jaringan keras gigi yang merusak struktur email, dentin dan sementum. Penyebab karies adalah aktivitas jasad renik (mikroorganisme jenis laktobasilus) yang melakukan proses peragian pada plak di permukaan gigi. Proses peragian ini menghasilkan suatu kondisi asam pada permukaan email yang pada akhirnya terjadi karies. $^{1}$

Di Indonesia kesehatan gigi dan mulut masih merupakan masalah yang perlu mendapat perhatian serius dari pemerintah dan tenaga kesehatan gigi. Hal ini disebabkan karena tingginya angka kejadian masalah gigi dan mulut di Indonesia, yakni sekitar $90 \%$ penduduk menderita penyakit gigi dan mulut. ${ }^{2}$ Berdasarkan hasil Riset Kesehatan Dasar Nasional (RISKESDAS) Tahun 2013, masalah gigi dan mulut khususnya di Provinsi Sulawesi Utara sebesar 31,6\% dan karies sebagai salah satu penyebab masalah gigi dan mulut dengan persentase sebesar $5,4 \%{ }^{3}$

Karies merupakan penyakit pada jaringan keras gigi. Salah satu faktor pendukung yang menyebabkan terjadinya karies gigi yaitu debris atau sisa-sisa makanan yang terdapat di sekitar gigi. Debris adalah material lunak yang terdapat pada permukaan gigi, terdiri dari lapisan biofilm, material alba, dan sisa makanan. Debris mempunyai pengaruh yang cukup besar terhadap proses terjadinya karies. ${ }^{4}$ Permukaan gigi yang dijaga kebersihannya dari debris lebih bertahan terhadap karies. Konsumsi buah-buahan yang mengandung serat dan air membantu pemeliharaan permukaan gigi dari debris sehingga karies gigi dapat dicegah. ${ }^{5}$

Pepaya merupakan tanaman buah yang terdapat hampir di semua daerah di Indonesia. Buah pepaya merupakan sumber vitamin, mineral, serat, dan mengandung enzim yang berguna untuk pencernaan. ${ }^{6} \mathrm{Di}$ dalam pepaya terdapat kadar air yang cukup tinggi dan kadar serat sebesar 0,7 gram tiap 100 gram daging buah pepaya, yang dapat membantu pengeluaran saliva lebih banyak serta dapat memberikan efek pembersihan sendiri gigi geligi (self cleansing effect). ${ }^{7}$

Usia 8-10 tahun merupakan kelompok usia yang kritis terhadap terjadinya karies gigi dan mempunyai sifat khusus yaitu transisi pergantian gigi susu ke gigi permanen. Prevalensi karies gigi anak usia 8-10 tahun mencapai 60-85\%. Dengan demikian dibutuhkan upaya preventif sedini mungkin yang dilakukan secara sistematik pada anak untuk mengatasi karies gigi. Pemilihan murid Sekolah Dasar (SD) sebagai obyek Usaha Kesehatan Gigi Sekolah (UKGS) sangat penting mengingat kurangnya perhatian akan kesehatan gigi anak usia sekolah dasar.

Penelitian ini bertujuan untuk mengetahui perbedaan antara konsumsi pepaya (Carica papaya) jenis California dengan jenis Hawai dalam menurunkan indeks debris pada anak. Sekolah Dasar Inpres Kaiwatu Kairagi Dua Manado diambil sebagai lokasi penelitian karena SD ini tidak memiliki program Usaha Kesehatan Gigi Sekolah (UKGS).

\section{METODE PENELITIAN}

Jenis penelitian ini ialah eksperimental dengan rancangan pra-eksperimental jenis one-shot case study dan pendekatan pretest-posttest. Penelitian ini dilaksanakan di SD Inpres Kaiwatu Kairagi Dua Manado pada bulan Oktober 2017.

Populasi penelitian ini ialah siswa SD Inpres Kaiwatu Kairagi Dua Manado berusia 8-10 tahun berjumlah 40 orang. Teknik pengambilan sampel menggunakan total sampling dan sesuai dengan kriteria inklusi dan eksklusi diperoleh 32 orang yang terdiri dari 16 siswa perempuan dan 16 siswa laki-laki sebagai responden

Alat yang digunakan berupa kaca 
mulut, piala ginjal, gelas kumur, wadah untuk sterilisasi alat, timbangan makanan, senter dan sonde. Bahan yang digunakan berupa buah pepaya California, buah pepaya Hawai, masker, sarung tangan, alkohol, air dalam kemasan, kapas, air bersih untuk membersihkan alat, kain putih ukuran kecil, air kumur, dan biskuit.

Pengambilan data dilakukan dengan memeriksa intraoral untuk mengukur indeks debris sebelum (pre-test) dan sesudah (post-test) mengonsumsi baik papaya California maupun papaya Hawai.

Sebelum indeks debris awal diperiksa, responden mengonsumsi biskuit sebanyak 30 gram setiap orang. Setelah biskuit selesai dimakan langsung diukur skor debris pada gigi geligi indeks yang akan diperiksa dengan menggunakan sonde dan kaca mulut. Hasil pengukuran skor debris dicatat di formulir pemeriksaan indeks debris dan setelah semua skor gigi indeks diukur, selanjutnya dihitung indeks debrisnya.

Responden dibagi menjadi 2 kelompok, masing-masing responden diberikan buah pepaya California dan buah pepaya Hawai dalam potongan-potongan kecil menjadi 4 potongan masing-masing 25 gram yang dikunyah sebanyak 8 kali dengan menggunakan pengunyahan pada ke 2 sisi rahang (kiri dan kanan). Setelah mengonsumsi buah pepaya California dan buah pepaya Hawai selama 5-10menit, dilakukan lagi pemeriksaan debris pada gigi geligi dengan menggunakan sonde dan kaca mulut. Hasil pengukuran skor debris dicatat pada formulir pemeriksaan untuk selanjutnya dihitung indeks debrisnya menggunakan skor debris menurut Greene dan Vermilion.

Data dianalisis menggunakan uji Shapiro-Wilk dan uji komparasi menggunakan uji Independent t-test untuk melihat pengaruh konsumsi buah pepaya California dan buah pepaya Hawai terhadap penurunan indeks debris.

\section{HASIL PENELITIAN}

Pada penelitian ini, didapatkan jumlah responden laki-laki dan perempuan sama banyak, yaitu masing-masing 16 siswa.
Jumlah responden terbanyak berdasarkan usia terdapat pada kelompok usia 8 tahun sebanyak 18 siswa $(56,25 \%)$, sedangkan kelompok usia 9 tahun sebanyak 10 siswa $(31,25 \%)$ dan kelompok usia 10 tahun sebanyak 4 siswa 12,5\%) (Tabel 1).

Kelompok usia 8 tahun terdiri dari 10 siswa yang mengonsumsi pepaya California dan 8 siswa yang mengonsumsi pepaya Hawai. Kelompok usia 9 tahun terdiri dari 3 siswa yang mengonsumsi pepaya California dan 7 siswa mengonsumsi pepaya Hawai. Kelompok usia 10 tahun terdiri dari 1 siswa mengonsumsi pepaya California, dan 4 siswa mengonsumsi pepaya Hawai (Tabel 1).

Tabel 1. Karakteristik responden berdasarkan usia dalam tahun

\begin{tabular}{|c|c|c|c|c|}
\hline \multirow{2}{*}{$\underset{\text { (tahun) }}{\text { Usia }}$} & \multicolumn{2}{|c|}{ Konsumsi pepaya } & \multirow[t]{2}{*}{$\mathbf{n}$} & \multirow[t]{2}{*}{$\%$} \\
\hline & California & Hawai & & \\
\hline 8 & 10 & 8 & 18 & 56,25 \\
\hline 9 & 3 & 7 & 10 & 31,25 \\
\hline 10 & 3 & 1 & 4 & 12,5 \\
\hline Total & 16 & 16 & 32 & 100 \\
\hline
\end{tabular}

Tabel 2 menunjukkan bahwa sebelum mengonsumsi pepaya California nilai indeks debris terendah sebesar 1,0 dan nilai tertinggi sebesar 2,7 dengan rerata 1,90 dan simpang baku 0,476. Sesudah mengonsumsi pepaya California nilai indeks debris terendah sebesar 0,0 dan nilai indeks debris tertinggi sebesar 1,0 dengan rerata 0,59 dan simpangan baku 0,273 . Pada nilai indeks debris terendah didapatkan selisih penurunannya 0,60 sedangkan pada nilai tertinggi didapatkan selisih penurunannya 2,0. Nilai t hasil uji yakni 11,864 dengan $P<0,0001$.

Tabel 3 menunjukkan bahwa sebelum mengonsumsi pepaya Hawai nilai terendah indeks debris sebesar 1,0 dan nilai tertinggi 2,8 dengan rerata 2,07 dan simpang baku 0,549. Sesudah mengonsumsi pepaya Hawai nilai indeks debris terendah sebesar 0,0 dan nilai indeks tertinggi 1,0 dengan rerata 0,36 dan simpangan baku 0,418 . Pada nilai indeks debris terendah, selisih penurunannya 0,80 sedangkan pada nilai tertinggi selisih penurunannya 1,71 . Nilai $\mathrm{t}$ hasil uji yakni 14,227 dengan $P<0,0001$. 
Tabel 4 menunjukkan nilai terendah penurunan indeks debris setelah mengonsumsi pepaya California sebesar 0,6 dan nilai tertinggi 2,0 dengan rerata 0,443 sedangkan nilai terendah penurunan indeks debris setelah mengonsumsi pepaya Hawai 0,8 dan nilai tertinggi 2,7 dengan rerata 0,481 . Nilai t hasil uji yakni $-2,447$ dengan $P=0,010$.

Tabel 2. Nilai deskriptif indeks debris sebelum dan sesudah konsumsi pepaya California dan hasil uji t berpasangan

\begin{tabular}{ccccc}
\hline Uji statistik & Sebelum & Sesudah & Penurunan & Hasil uji \\
\hline Nilai terendah & 1,0 & 0,0 & 0,60 & \\
Nilai tertinggi & 2,7 & 1,0 & 2,0 & $\mathrm{t}=11,864$ \\
Rerata & 1,90 & 0,59 & 1,31 & $(P<0,0001)$ \\
Simpangan baku & 0,476 & 0,273 & 0,443 & \\
\hline
\end{tabular}

Tabel 3. Nilai deskriptif indeks debris sebelum dan sesudah konsumsi pepaya Hawai dan hasil uji t berpasangan

\begin{tabular}{lcccc}
\hline \multicolumn{1}{c}{ Uji statistik } & Sebelum & Sesudah & Penurunan & Hasil uji \\
\hline Nilai Terendah & 1,0 & 0,0 & 0,80 & \\
Nilai Tertinggi & 2,8 & 1,0 & 2,7 & $\mathrm{t}=14,227$ \\
Rerata & 2,07 & 0,36 & 1,71 & $(P<0,0001)$ \\
Simpangan baku & 0,549 & 0,418 & 0,481 & \\
\hline
\end{tabular}

Tabel 4. Nilai deskriptif penurunan indeks debris kedua jenis pepaya dan hasil uji t tidak berpasangan

\begin{tabular}{lccc}
\hline \multicolumn{1}{c}{ Uji statistik } & Pepaya & Hasil uji \\
& California & Hawai & \\
\hline Nilai terendah & 0,6 & 0,8 & \\
Nilai tertinggi & 2,0 & 2,7 & $\mathrm{t}=-2,447$ \\
Rerata & 1,31 & 1,71 & $(P=0,010)$ \\
Simpangan baku & 0,443 & 0,481 & \\
\hline
\end{tabular}

\section{BAHASAN}

Pada penelitian ini, diambil 32 sampel siswa-siswi SD Inpres Kaiwatu Kairagi Dua Manado dengan rentang usia 8-10 tahun dan dilakukan penghitungan indeks debris setelah mengonsumsi pepaya California dan pepaya Hawai. Responden penelitian ini terdiri dari 16 siswa laki-laki (50\%) dan 16 siswa perempuan (50\%).

Berdasarkan kategori usia didapatkan responden terbanyak berusia 8 tahun $(56,3 \%)$, diikuti yang berusia 9 tahun $(31,3 \%)$, dan yang berusia 10 tahun $(12,5 \%)$. Responden dibagi atas dua kelompok, salah satu kelompok mengonsumsi pepaya California dan kelompok lainnya mengonsumsi pepaya Hawai.

Sebelum dilakukan ujian perbedaan indeks debris sebelum dan sesudah mengonsumsi pepaya California, dilakukan uji normalitas data indeks debris untuk melihat apakah data penurunan indeks debris menyebar normal. Hasil uji kenormalan data dengan Uji Shapiro-Wilk menyatakan data penurunan indeks debris menyebar normal sebab nilai $P=0,428$. Oleh karena data penurunan indeks debris menyebar normal, maka uji perbedaan indeks debris sebelum dan sesudah mengonsumsi pepaya California menggunakan uji-t berpasangan yang mendapatkan $\mathrm{t}=11,864$ dengan $P<0,0001$ (Tabel 2). Dengan demikian terdapat penurunan indeks debris yang sangat bermakna pada responden yang mengonsumsi pepaya California. Hasil ini menunjukkan adanya 
pengaruh konsumsi pepaya California terhadap penurunan indeks debris responden.

Data penurunan indeks debris sebelum mengonsumsi dan setelah mengonsumsi pepaya Hawai diuji kenormalannya dengan uji Shapiro-Wilk yang menyatakan data tersebut menyebar normal $(P=0,229)$. Oleh karena itu untuk perbedaan indeks debris sebelum dan sesudah mengonsumsi pepaya Hawai diuji dengan uji-t berpasangan. Dari hasil uji ini diperoleh $\mathrm{t}=$ 14,227 dengan $P<0,0001$ (Tabel 3) yang menyatakan terdapat penurunan indeks debris yang sangat bermakna pada responden yang mengonsumsi pepaya jenis Hawai. Hasil ini menunjukkan adanya pengaruh konsumsi pepaya Hawai terhadap penurunan indeks debris.

Penurunan indeks debris setelah mengonsumsi pepaya California dan pepaya Hawai disebabkan karena kedua jenis pepaya merupakan makanan berserat. Hal ini sejalan dengan penelitian Huda et al. ${ }^{9}$ yang mengguinakan buah apel Fuji. Buahbuahan merupakan makanan yang kaya serat dan berbagai macam vitamin. ${ }^{9}$ Serat dalam buah-buahan merupakan pembersih alamiah pada permukaan gigi geligi, membantu menyingkirkan partikel-partikel makanan dan gula selama proses mengunyah.

Buah pepaya juga mempunyai kadar air yang cukup tinggi. ${ }^{5}$ Adanya kandungan air dalam buah pepaya, baik pepaya California maupun pepaya Hawai dapat membantu atau melancarkan proses pembersihan debris pada permukaan gigi. Kandungan serat dan air yang tinggi pada buah pepaya memberikan efek self cleansing pada permukaan gigi geligi. Hal ini selaras dengan hasil penelitian Cahyati ${ }^{10}$ yang menyatakan bahwa buah pepaya baik untuk dikonsumsi karena memiliki kadar air yang tinggi dan memiliki daya membersihkan gigi sendiri atau self cleansing effect.

Proses mengunyah makanan berserat juga akan merangsang dan meningkatkan produksi saliva. Proses ini secara perlahan akan mengurangi pembentukan plak gigi dan karies. ${ }^{11}$ Saliva membantu membilas gigi dari partikel-partikel makanan yang melekat pada gigi, dan juga melarutkan komponen gula dari sisa makanan yang terperangkap dalam sela-sela pit dan fisur permukaan gigi. ${ }^{1}$

Berdasarkan hasil uji kenormalan data dengan Uji Shapiro-Wilk diperoleh hasil bahwa data penurunan indeks debris pada kedua jenis pepaya menyebar normal, $(P$ $>0,05)$. Oleh karena data penurunan indeks debris pada kedua jenis pepaya menyebar normal, maka uji perbedaan penurunan indeks debris setelah mengon-sumsi pepaya diuji dengan uji-t tidak berpasangan yang mendapatkan nilai $\mathrm{t}=-2,447$ dengan $P=$ $0,010<0,05$ (Tabel 4). Hasil uji ini menyatakan bahwa terdapat perbedaan bermakna pada penurunan indeks debris responden yang mengonsumsi pepaya California dan pepaya Hawai. Rerata penurunan indeks debris pada pepaya Hawai lebih tinggi (1,71) dibandingkan dengan rerata penurunan indeks debris pada pepaya California (1,31) sehingga dapat disimpulkan bahwa konsumsi pepaya Hawai lebih berpengaruh terhadap penurunan indeks debris dibandingkan konsumsi pepaya California.

Penulis berasumsi bahwa mengonsumsi pepaya Hawai lebih berpengaruh terhadap penurunan indeks debris daripada mengonsumsi pepaya California dikarenakan pepaya Hawai memiliki kadar air yang lebih tinggi daripada pepaya California. Hal ini terlihat dari tekstur daging buah dalam keadaan matang yang lebih lembut dan mudah hancur dibandingkan tekstur pepaya California.

\section{SIMPULAN}

Berdasarkan hasil penelitian ini dapat disimpulkan bahwa terdapat pengaruh bermakna mengonsumsi buah pepaya (Carica papaya) California dan Hawai terhadap penurunan indeks debris anak usia 8-10 tahun. Konsumsi pepaya Hawai lebih berpengaruh secara bermakna terhadap penurunan indeks debris dibandingkan dengan pepaya California. 


\section{SARAN}

Disarankan bagi pihak puskesmas yang bertanggungjawab atas kesehatan masyarakat di wilayah kerjanya, agar mensosialisasikan kepada masyarakat serta mendorong masyarakat untuk mengonsumsi buah pepaya sebagai buah lokal yang mudah diperoleh, terlebih khusus pepaya Hawai mengingat manfaatnya yang baik bagi kebersihan dan kesehatan gigi.

Disarankan bagi tenaga kesehatan gigi, terlebih khusus para dokter gigi yang berpraktek untuk membantu mensosialisasikan kepada pasien dan keluarga tentang pemanfaatan pepaya yang sebagai buah lokal yang relatif murah dan tidak sulit diperoleh namun memiliki manfaat yang baik bagi kebersihan dan kesehatan gigi.

Disarankan adanya penelitian sejenis yang dilakukan dengan pepaya dari jenis yang berbeda untuk mengetahui jenis pepaya yang memiliki pengaruh paling besar terhadap penurunan indeks debris.

\section{DAFTAR PUSTAKA}

1. Pratiwi R, Mutmainnah R. Gambaran keparahan karies pada anak usia 6,9 dan 12 tahun di Kabupaten Pinrang, Sulawesi Selatan menggunakan indeks PUFA/pufa. Dentofasial. 2013; 12(2):76.

2. Indirawati T, Sintawati FX, Yovita A.T. Gambaran karies gigi permanen di beberapa puskesmas Kota dan
Kabupaten Bandung, Sukabumi serta Bogor. 2009; h.1-3.

3. Riset Kesehatan Dasar. Badan penelitian dan pengembangan kesehatan. Jakarta: Departemen Kesehatan Republik Indonesia, 2013; p. 111-2.

4. Lusnarnera R, Tendean LEN, Gunawan PN. Pengaruh konsumsi semangka (citrullus lanatus) dalam menurunkan indeks debris pada anak usia 8-10 tahun. eG. 2016;4(1):54.

5. Darby ML, Walsh MM. Dental hygiene theory and practice (3rd ed). Canada: Saunders Elsevier, 2010; p.281-339.

6. Pusat data dan informasi pertanian. Analisis konsumsi pangan. Departemen Pertanian, 2009; p. 91.

7. Santoso S, Ranti AL. Buku Kesehatan dan Gizi. Jakarta: PT Rineka Cipta, 2008.

8. Hadayanti S, Suyatmi D. Pengaruh mengunyah apel dan jambu biji merah terhadap debris indeks. Jurnal Kesehatan Gigi. 2016;3(2):42.

9. Huda HH, Aditya G, Praptiningsih RS. Efektivitas konsumsi buah apel (Pyrus malus) jenis Fuji terhadap skor plak gigi dan $\mathrm{pH}$ Saliva. Dentino. 2014;2(1):10.

10. Cahyati WH. Konsumsi pepaya dalam menurunkan debris indeks, Jurnal Kesehatan Masyarakat. 2013;8(2): 12736.

11. Bangun AP. Vegetarian Pola Hidup Sehat Berpantang Daging (4th ed). Jakarta: Agromedia Pustaka, 2009; p. 10. 